\title{
Biodegradation of Used Engine Oil By Bacteria Isolated From Soil Contaminated With Used Engine Oil in Ogbomoso, Nigeria
}

\author{
Eniola K.I.T, Adegbola G.M. And Opasola O.A. \\ ${ }^{I}$ Department of Biological Sciences, Joseph Ayo Babalola University, Ikeji-Arakeji \\ ${ }^{2}$ Department of Food Science and Engineering (Food Microbiology Laboratory), LadokeAkintola University of \\ Technology, P.M.B 4000 Ogbomoso. \\ ${ }^{3}$ Department of Pure and Applied Biology, LadokeAkintola University of Technology, P.M.B 4000 Ogbomoso.
}

\begin{abstract}
The biodegradation potential of five bacteria isolated from used engine oil contaminated soil was investigated in this study. The bacteria were inoculated into used oil supplemented with Mineral Salt Medium and incubated at $37^{\circ} \mathrm{C}$ for 25 days. The results obtained showed that all the bacteria were able to utilize the engine oil as source of carbon. IR analysis of the residual engine oil showed that the bacteria have exerted microbial action on the oil. The results obtained from IR analysis revealed 9 bands in P. vulgaris, B. cereus, $S$. typhi, S. faecium, 10 bands for P. aeruginosa while that of the control was recorded to 8 bands. This study showed that the bacteria strains used in this study could be relevant in the bioremediation of ecosystem that may be contaminated with hydrocarbons.
\end{abstract}

Keyword: Biodegradation, MSM, Residual oil, Bioremediation.

\section{Introduction}

Used motor oil is the brown-to-black oily liquid removed from a motor vehicle, when the oil is changed. Used motor oil is similar to unused oil, except that it contains additional chemicals that are produced or build up in the oil, when it is used as an engine lubricant at high temperatures and pressures, inside an engine as it runs (Dorsey et al., 1997). Used motor oil also contains metals such as aluminium, chromium, copper, iron, lead, manganese, nickel, silicon and tin that comes from engine parts, as they wear down (Keith and Telliard, 2003).

Some of these metals in used motor oil can dissolve in water and move through the soil easily, and may be found in surface water and ground water. Thus, metals from used oils can build up in plants, animals, soil, sediments and non-flowing surface water. Heavy metals and chemicals in used motor oil are absorbed and distributed into various tissues of human, plants and animals by their movement in the environment, which can result in serious health problem, such as anemia, tremor and consequently, resulting in death (Keith and Telliard, 2003). Other health hazards which can result from used motor oil include mutagenicity and carcinogenicity (Boonchan et al., 2000).

In most countries of the world, oil spills at auto-mechanic workshops have been left uncared for over the years, and its continuous accumulation is of serious environmental concern because of the hazard associated with it. The physicochemical treatment technologies currently in use are expensive and not environmentally friendly. In addition, some of these technologies only transfer the contamination from one place to another.

In recent times, a lot of efforts have been made towards reducing environmental pollution, by using natural processes to treat environmental pollution. These techniques include: bioremediation (use of microorganisms to degrade pollutants) and phytoremediation (use of plants to clean pollutants by bioaccumulation into the plant's tissues).

Bioremediation is the naturally occurring process by which micro-organisms transform environmental contaminants into harmless end-products, in order to obtain the sources of carbon and energy. During the process of bioremediation, which involves the activity of micro-organisms to remove pollutants, environmental parameters such as temperature, $\mathrm{pH}$, oxygen and moisture content, are optimized to achieve accelerated biodegradation. Basically, there are two different approaches to bioremediation technologies, depending on the pollution situation and type of micro-organisms being used. The first is the one which involves the activation of the indigenous microflora in the polluted area by addition of nutrients and forming the best conditions of other chemical, physical and biological factor, or known as biostimulation. The second (bioaugumentation) is the one which involves the addition of oil-oxidizing micro-organisms isolated from other sites, or addition of genetically engineered micro-organisms (Amundet al., 1987). This study was primarily carried to investigate the bioremediation potentials of five bacteria Isolated from used engine oil contaminated soil in Ogbomoso, Oyo State, Nigeria. 


\section{Materials And Methods}

Five (5) Sampling sites were selected by observing regular practice of metal contaminated wastes in the vicinity of auto batteries and automobile workshops in Ogbomoso, Oyo state, Nigeria. Automobile workshops that has being in existence for more than five years were randomly selected.

Surface soil sample was collected from automobile workshops into sterile polythene bags and transported to the laboratory of the Department of Food Science and Engineering (Food Microbiology Laboratory) of Ladoke Akintola University of Technology, Ogbomoso, Oyo State Nigeria.

One gram of soil sample was suspended in $9 \mathrm{ml}$ sterile distilled water and was diluted serially up to 1010. $0.2 \mathrm{ml}$ (aliquot) of the suspension was inoculated separately in to Nutrient agar plates. The plates were incubated at $35^{\circ} \mathrm{C}$ for $24-72$ hours. Distinct colonies growing on each plate were selected, subcultured and stored in glycerol broth at freezing temperatures. The bacteria were identified by using the method described in Bergey manual of systematic bacteriology.

Used engine oil used for this study was sterilized by tyndallization. This was carried out in the water bath at $80^{\circ} \mathrm{C}$ for 3 hour for 3 days.

In other to meet with nutritional requirement of the bacteria isolates for proper growth MSM was prepared using the following salts: $\mathrm{KH}_{2} \mathrm{PO} 4$ (2.0g/l), $\mathrm{NaNO}_{3}(2.0 \mathrm{~g} / \mathrm{l})$, Nacl $(0.8 \mathrm{~g} / \mathrm{l})$, $\mathrm{Kcl}(0.8 \mathrm{~g} / \mathrm{l})$, $\mathrm{Na}_{2} \mathrm{HPO}_{4} \cdot 12 \mathrm{H}_{2} \mathrm{O}(2.0 \mathrm{~g} / \mathrm{l}), \mathrm{MgSO}_{4}(0.2 \mathrm{~g} / \mathrm{l})$ and $\mathrm{FeSO}_{4} \cdot 7 \mathrm{H}_{2} \mathrm{O}(0.001 \mathrm{~g} / \mathrm{l})$. All the salts were dissolved in one litre (1L) of water, and sterilized in autoclave at $121^{\circ} \mathrm{C}$ for 15 minutes.

The bacteria isolate was transferred into fresh Nutrient plates and incubated at $35^{\circ} \mathrm{C}$ for 24 hours. The cells of the bacteria isolate were washed into sterile test tubes, using sterile distilled water.

$45 \mathrm{ml}$ of MSM was dispensed into 20 sterile bottles, $5 \mathrm{ml}$ of tyndalize used engine oil was dispensed aseptically into the bottles, $2 \mathrm{ml}$ of the washed cells was aseptically inoculated into all the oil-MSM bottles. The bottles were incubated at $35^{\circ} \mathrm{C}$, for 25 days.

\section{Extraction of residual oil}

The residual oil in the experimental bottles and control bottles was extracted by using liquid - liquid solvent extraction method. The organic solvent used was chloroform. This was done by measuring $50 \mathrm{ml}$ of chloroform into the bottles containing OIL-MSM, the contents were later transferred into separating funnel. The funnel was allowed to stand for two hours, the layer containing the organic solvent and residual oil was emptied into a pre-cleaned container, the organic solvent was allowed to evaporate, after the evaporation the residual oil was collected and stored for further analysis.

\section{Infrared analysis}

The residual oil recovered from both control and experimental bottles was subjected to IR analysis after 25 days of incubation at the Central research Laboratory of University of Ibadan, Nigeria.

\section{Results And Discussion}

The bacteria isolates were characterized to be Proteus vulgaris, Bacillus cereus, Salmonella typhi, Streptococcus faecium and Pseudomonas aeruginosa.

The results of infrared analysis of the residual oil that all the aforementioned bacteria acted upon under the same condition are presented in Figure 1 to 6 . The results revealed different patterns and bands when compared with the control. The results obtained from IR analysis revealed 9 bands in P. vulgaris, B. cereus, S. typhi, S. faecium, 10 bands for $P$. aeruginosa while that of the control was recorded to 8 bands. The results indicated that all the bacteria have varying ability to biodegrade the used engine oil. Among all the bacteria $P$. aeruginosa seems to have innate potential to biodegrade hydrocarbons due to the fact that the bacterium is the only that produced ten bands (Figure 5). 


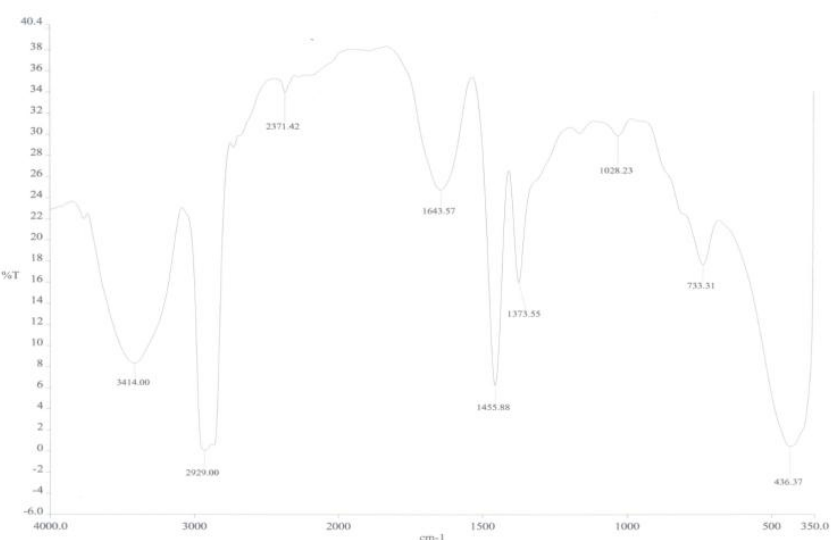

Fig 1: Infrared Analysis Of Used Oil Acted Upon By Bacillus Cereus

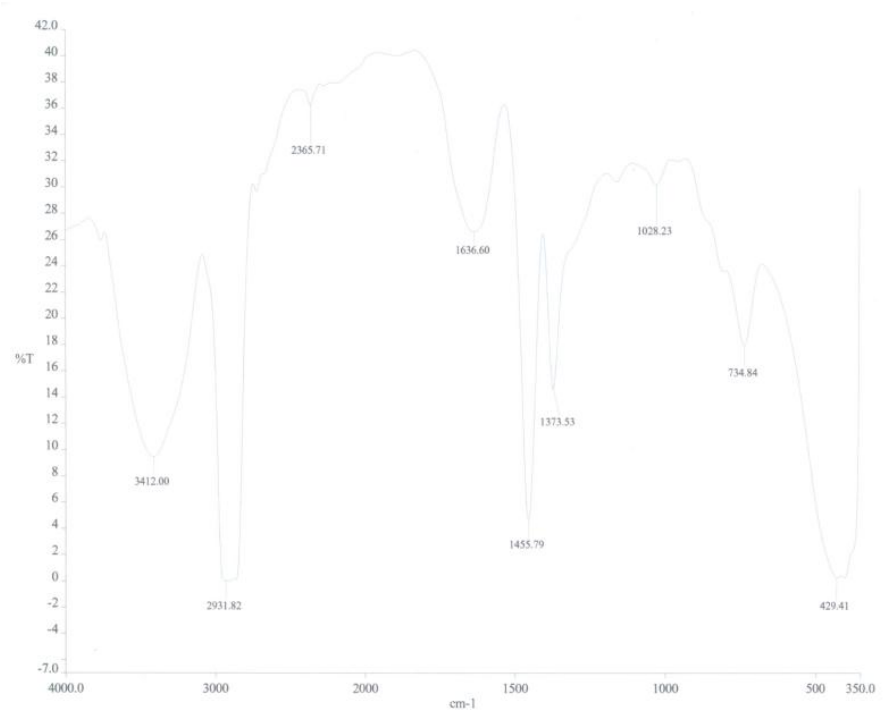

Fig 2:Infrared Analysis On Proteus Vulgaris

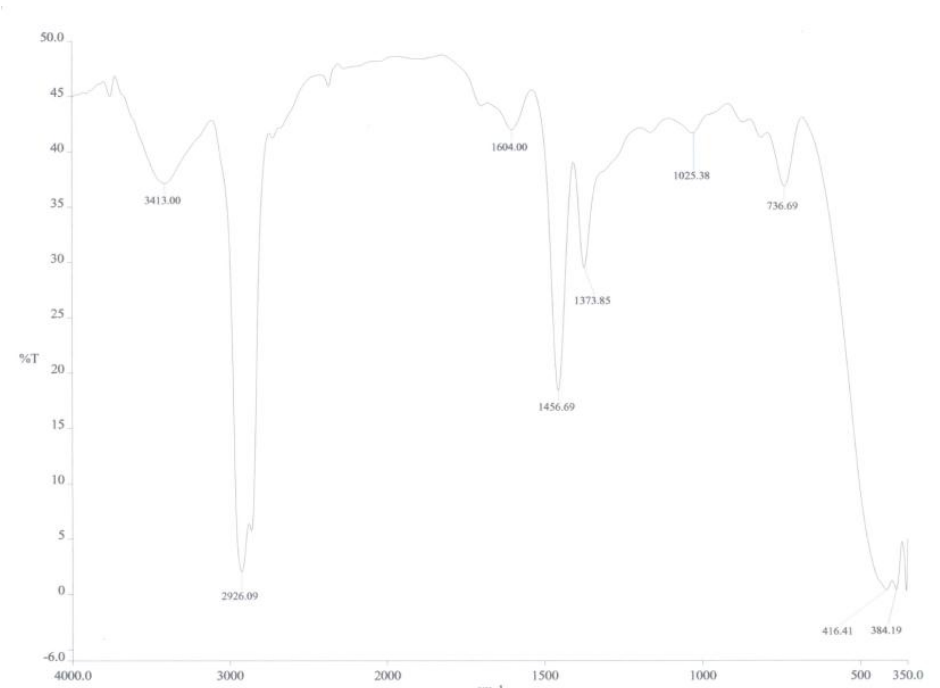

Fig 3:Infrared Analysis Of Used Oil Acted Upon By Salmonella Typhil 


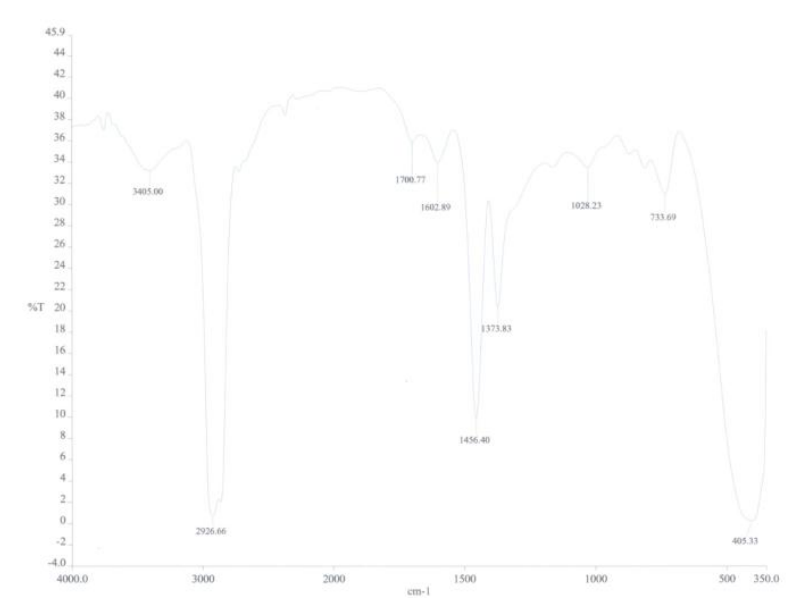

Fig 4: InfraredAnalysis Of Used Oil Acted Upon By Streptococcus Faecium

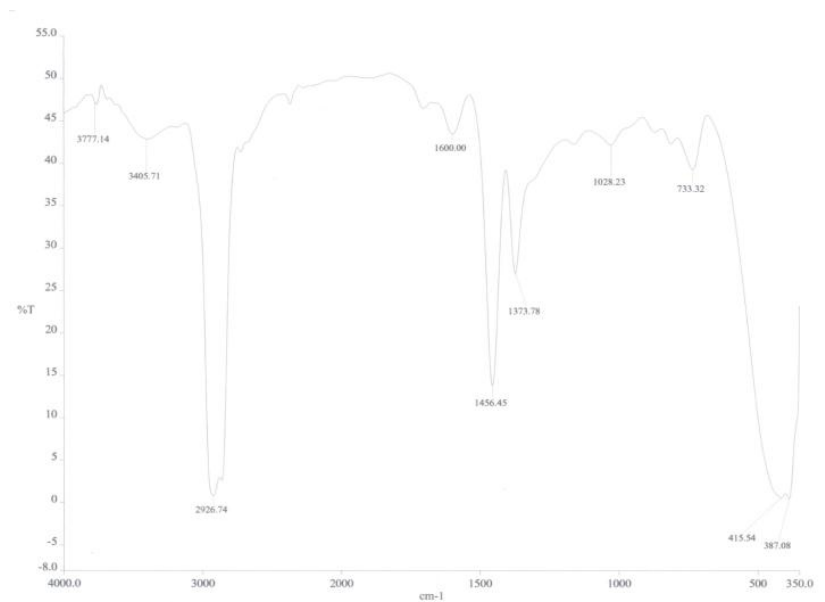

Fig 5:Infrared Analysis Of Used Oil Acted Upon By Pseudomonas Auriginosa

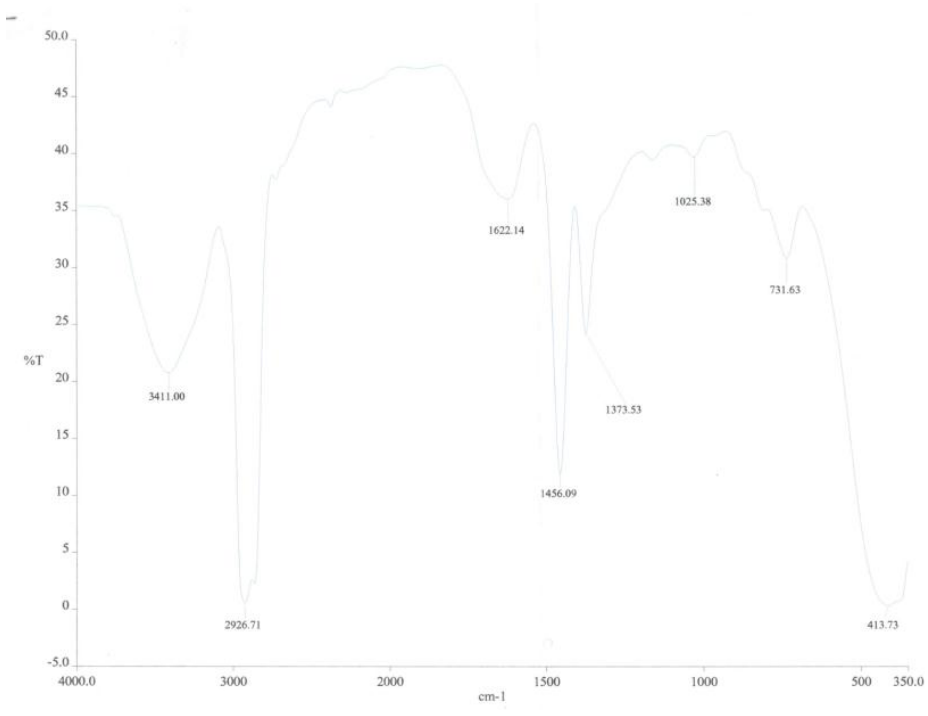

Fig 6: Infrared Analysis Of Control Without Microorganism 


\section{Discussion}

Today the use of microorganisms for removing oil pollution from contaminated sites is gaining popularity because other methods such as surfactant washing and incineration lead to production of more toxic compounds and they are non-economical (Margesin, 2000; Barathiet al., 2002). There are so many bacteria with this ability and these organisms are widely distributed in soil, marine and freshwater habitats (Opasola and Adewoye, 2010; Opasola et al., 2011).

It has been documented in many studies that most potential bacteria for petroleum hydrocarbon degradation have been isolated from areas contaminated with oil (Chaerun et al ., 2004). Since all the bacteria isolates used in this study were isolated from oil contaminated soil, the innate potential of degradation exhibited by these bacteria isolates is in conformity with the reports of Chaerun et al ., (2004) and Vidalii (2001).

A large number of Pseudomonas spp capable of degrading polycyclic aromatic hydrocarbons have been reported in many studies (Zhang et al,2005). Bacillus spp capable of degrading hydrocarbon have also been reported (Nwagwuet al.,2008). High degradability potential recorded for P. aeruginosa in this study follows the same trend with the reports of Das and Mukhererjee, (2003); Antai and Mgbomo (1993). This may be due to the fact that Pseudomonas spp is a common bacterium capable of degrading hydrocarbons. Many studies have also reported the efficiency of Pseudomonas spp in degradation of hydrocarbons such as benzenes (Munoz et al., 2007), toluene, P- xylene (Yu et al , 2001), biphenyl (Ohtaet al., 2001) and phenol (Yuang and Tsai, 2006). Therefore encountering P.aeruginosa and its high degradability potential exhibited in this study is not rare.

However, degradation of used oil by the 5 bacteria isolates was possible because microorganism have been reported to have enzymatic systems which empower them to degrade and utilize petroleum hydrocarbon as source of carbon and energy (Antai and Mgbomo, 1993; Ezejiet al., 2005). Biodegradation of crude oil by microorganisms have been reported to be a natural process by which the bulk of the polluting oil is used as an organic carbon sources, causing breakdown of petroleum components to lower molecular compounds or transferred into the other organic compounds or into energy, cells mass and biological products.

\section{Conclusion}

This study showed that Proteus vulgaris, Bacillus cereus, Salmonella typhi, Streptococcus faecium and Pseudomonas aeruginosa isolated from used oil contaminated soil have ability to degrade. Therefore, the bacteria isolates used in this study could be relevant in the abatement of ecosystems that may be contaminated with hydrocarbons. This study shows that bioremediation can be used effectively to treat oil contaminated soil using microorganism that are indigenous to the contaminated sites.

\section{References}

[1]. Antai , S.P and Mgbomo, E. W.A.J Biol. Appl chem. 1993,38,16-20.

[2]. Amund OO, Adebowale AA, Ugoji EO, Indian J Microbiol, 1987, 27: 63-67.

[3]. Atlas RM, CernigliaCE Bioscience, 1995 45: 332-338.

[4]. BarathiS, Vasudevan N. Utilization of petroleum hydrocarbons by pseudomonas fluorescens

[5]. Boonchan S, Britz ML, Stanley GA ,Appl Environ Microbiol, 2000 66: 1007-1019.

[6]. Chaerun, S.K, Tazaki, K., Asada R. and Kogure, K .Environmental international 2004, 30,

[7]. Das, K and Mukherjee, A.K. Bioresources Technology 2007, 28,1339-45

[8]. Ezeji, E.U Anyanwu, B,N, Onyeze G.O.C Ibekwe V.I. Int. J. Nat Applsc.2005, 1, 122-128.

[9]. isolated from petroleum contaminated soil., 2002, 26; 413-416

[10]. Keith L, TelliardWEnvironSciTechnol, 1979, 13: 416-423.

[11]. Lee LS, Hagwell M, Delfino JJ, Rao PSC Environ SciTechnol, 1992 26: 2104-2110.

[12]. Munoz, R., Diaz, L.F, Bordel, S. and Villaverde, S. Chemosphere, 2007, 68, 244-52.

[13]. Nwaogu, L.A Onyeze, G. O.C, and Nwabueze , R.N . Afri J. of Biotech 2008,18,1937-

[14]. Olita, Y, Maeda, M and Kudo, T. Microbiology 2001,147,31-41.

[15]. Opasola O.A., Adewoye S.O, Adewoye A.O and Bolaji A.S. European Journal of Experimental Biology. 2011 1(2): $187-197$.

[16]. Opasols O.A and Adewoye S.O. Journal of Advances in Applied Sciences, 2010 1(1):182-188.

[17]. Vidalii,M. Pure Appl Chem. 2001,73,11-1172.

[18]. Yu, H, Kim B.J, and Rittmann, B.E.Biodegradation 2001,12: 455-63.

[19]. Zhang G, WU, Y, Qian, X, and Meng Q,.J. zhanguniv.2005,6,725-73 